\title{
O DESIGN DE TEXTOS MULTISSEMIÓTICOS: IMPLICAÇÓES PARA O PROCESSO DE PRODUÇÃO DE SENTIDOS
}

\author{
Helena Maria Ferreira ${ }^{1}$ \\ Guilherme Melo $^{2}$ \\ Taísa Rita Ragi ${ }^{3}$
}

\begin{abstract}
Resumo: Este artigo tem por objetivo precípuo analisar os efeitos de sentido decorrentes das escolhas quanto à seleção, à apresentação e à disposição dos componentes e dos recursos integrantes de textos imagéticos. Para fundamentar a discussão, o artigo apresenta um compilado teórico acerca da multimodalidade, bem como um panorama dos princípios basilares da Gramática do Design Visual, proposta por Kress e van Leeuwen (2006). Este trabalho conta, ainda, com uma análise de uma campanha ambiental, em que são observados aspectos relativos à organizaçáo composicional das imagens, bem como os efeitos de sentido decorrentes das escolhas feitas pelo produtor da mensagem. A partir do trabalho empreendido, foi possível constatar que a leitura de imagens se reveste de complexidade, o que demanda uma fundamentaçáo teórica sólida para a implementação de práticas metodológicas capazes de propiciar novas incursões sobre os modos imagéticos para um dimensionamento das questôes culturais, estéticas, científicas, técnicas e artísticas integrantes dos textos multissemióticos, visando minimizar leituras realizadas de modo intuitivo ou ingênuo. A consideração das relaçóes estabelecidas entre os elementos constitutivos permite um enfrentamento da complexidade inerente ao processo de leitura de imagens, viabilizando a formação de um leitor mais crítico e ampliando os multiletramentos.
\end{abstract}

Palavras-chave: Leitura. Textos multissemióticos. Gramática do Design Visual.

1 Professora do Programa de Pós-graduação em Educação e do Programa de Pós-graduação em Letras, pela Universidade Federal de Lavras. Graduada em Letras pelo Centro Universitário de Patos de Minas (1993), em Letras (Português/Espanhol) pela Universidade de Uberaba (2010) e em Pedagogia pela Universidade Federal de Uberlândia (2013). Mestra em Linguística pela Universidade Federal de Uberlândia (1998) e doutora em Linguística Aplicada e Estudos da Linguagem pela Pontifícia Universidade Católica de São Paulo (2008). E-mail: helenaferreira@ ufla.br

2 Graduando em Letras (Português, Inglês e suas Literaturas) pela Universidade Federal de Lavras. E-mail: invernificar@gmail.com

3 Graduanda em Letras (Português, Inglês e suas Literaturas) pela Universidade Federal de Lavras. E-mail: taisaragi@gmail.com 


\title{
THE DESIGN OF MULTISEMIOTIC TEXTS: IMPLICATIONS FOR THE SENSE PRODUCTION PROCESS
}

\begin{abstract}
This article aims to analyze the effects of sense arising from the choices on the selection, presentation and arrangement of the components and resources of members pictorial texts. To support the discussion, this paper presents a theoretical compiled about the multimodality, as well as an overview of the basic principles of design Visual Grammar proposed by Kress and van Leeuwen (2006). This work offers an analysis of an environmental campaign, in which they are observed aspects of compositional organization of the images as well as the effects of meaning arising from the choices made by the message producer. From the work undertaken, it was found that the reading of images is of complexity, which requires a solid theoretical foundation for the implementation of methodological practices to provide further incursions on the imagistic modes for design of cultural, aesthetic issues, scientific, technical, artistic members of multisemiotic texts, in order to minimize readings performed intuitive or naive way. Consideration of the links between the constituent elements of referentialities, senses allows confronting the complexity inherent to the image reading process, enabling the formation of a more critical reader and expanding the multiliteracies.
\end{abstract}

Keywords: Reading. Multisemiotic texts. Grammar of Visual Design.

\section{Consideraçóes iniciais}

Com a emergência das tecnologias de comunicaçáo e de informação, novas demandas de leitura são impostas e novos gêneros discursivos passam a circular no meio social. Essas questóes ampliam as exigências para o ensino de Língua Portuguesa, que precisa contemplar o trabalho com textos multimodais/ multissemióticos nas suas realizaçóes verbais (fala e escrita) e não verbais (sons, imagens, gestos etc.), uma vez que a prática da leitura sofreu mudanças acentuadas pela diversidade de textos disponíveis em suporte digital e pelas experiências leitoras decorrentes da disseminaçáo do acesso à internet.

Nesse contexto digital, os textos ganham novos contornos, significados, valores e estruturação, exigindo do leitor novas habilidades leitoras que possibilitem a exploração do texto no suporte virtual - a web. Nessa direção, Coscarelli (1999) considera que o texto deixa de ser concebido como um todo contíguo (uma unidade formal) de estrutura unicamente linear, quase que unicamente verbal, para uma abordagem que o considera como uma nova estrutura hierárquica fragmentada, da qual fazem parte ícones, imagens estáticas e/ou animadas e sons. Essas novas configuraçóes convocam novos letramentos ${ }^{4}$, uma vez que contemplam usos sociais da linguagem que configuram os enunciados/textos em sua multissemiose (multiplicidade de semioses ou linguagens) ou multimodalidade.

4 Os estudos sobre letramento, no Brasil, foram introduzidos por Magda Soares. Além desses estudos, também se destacam nesse campo: KLEIMAN, A. B. (Org.). Os significados do letramento: uma nova perspectiva sobre a prática social da escrita. Campinas: Mercado das Letras, 2008. SOARES, Magda. Letramento: um tema em três gêneros. 3 ed. Belo Horizonte: Autêntica, 2009. SOARES, Magda. Alfabetização e letramento. 6 ed. São Paulo: Contexto, 2011. TFOUNI, L. V.. Letramento e Alfabetização. 9 ed. São Paulo: Cortez, 2010. 103 p. 
Para Rojo (2008), o surgimento e a ampliação significativa de acesso às tecnologias digitais de informação e de comunicação (computadores pessoais, celulares, TVs digitais, entre outras) implicaram, pelo menos, três mudanças que assumem relevância na reflexão sobre os letramentos socialmente requeridos:
a) a intensificação vertiginosa e a diversificação da circulação da informação nos meios de comunicação analógicos e digitais, que, pois isso mesmo, distanciam-se hoje dos meios impressos, muito mais morosos e seletivos, implicando, segundo alguns autores (CHARTIER, 1997; BEAUDOUIN, 2002), mudanças significativas nas maneiras de ler, de produzir e de fazer circular textos nas sociedades; b) a diminuição das distâncias espaciais - tanto em termos geográficos, por efeito dos transportes rápidos, como em termos culturais e informacionais, por efeito da mídia digital, desenraizando as populações e desconstruindo identidades, e a diminuição das distâncias temporais ou a contração do tempo, determinadas pela velocidade sem precedentes, pela quase instantaneidade dos transportes, da informação, dos produtos culturais das mídias, características que também colaboram para mudanças nas práticas de letramentos; c) a multissemiose que as possibilidades multimidiáticas e hipermidiáticas do texto eletrônico trazem para o ato de leitura: já não basta mais a leitura do texto verbal escrito - é preciso colocá-lo em relação com um conjunto de signos de outras modalidades de linguagem (imagem estática, imagem em movimento, fala, música) que o cercam, ou intercalam ou impregnam; esses textos multissemióticos extrapolaram os limites dos ambientes digitais e invadiram também os impressos (jornais, revistas, livros didáticos) (ROJO, 2008, p. 583-4).

Após essa breve contextualização acerca das interfaces entre tecnologias de informação e de comunicação nas práticas de linguagem, multiletramentos e ensino da leitura, este artigo tem por objetivo discutir as práticas de leitura dos textos imagéticos, considerando o valor semântico dos elementos constitutivos das imagens, sem desconsiderar, no entanto, sua inter-relação com o texto verbal. Para tal, adota como pressupostos teórico-metodológicos os princípios da Gramática do Design Visual (GDV), desenvolvida por Kress e van Leeuwen (2006) e seus seguidores. Para a consecução da proposta de discussáo, este artigo é composto por uma compilação teórica, que apresenta, de forma resumida, os fundamentos de uma abordagem pedagógica dos multiletramentos e a aplicabilidade da GDV como ferramenta analítica para a leitura sistemática de textos visuais.

Além da explanação teórica, o artigo apresenta uma análise de uma campanha educativa, a partir da perspectiva da GDV, com vistas a ilustrar como essa teoria pode ser aplicada à prática docente, de modo especial, às práticas de leitura de textos imagéticos. Dessa forma, este estudo assume relevância no sentido de disponibilizar uma proposta de reflexáo sobre a leitura de textos multissemióticos, que apesar de integrarem o cotidiano social, ainda não recebem a devida atençáo no contexto escolar. Assim, para a ampliação dos multiletramentos, é necessário que o leitor/ escritor proficiente saiba codificar/decodificar aspectos linguísticos do texto verbal (estruturas internas), depreender as características do contexto de produção e 
recepção dos textos e, também, interpretar os modos semióticos ${ }^{5}$ constituintes dos diversos gêneros discursivos que circulam na sociedade.

\section{Pressupostos teórico-metodológicos dos/sobre multiletramentos}

A partir da publicação dos Parâmetros Curriculares Nacionais - Língua Portuguesa (BRASIL, 1998) e da disseminação de várias pesquisas linguísticas de cunho interacionista, o ensino da leitura foi notadamente redimensionado. De início, a discussão foi centrada na perspectiva da diversidade de gêneros discursivos que passaram a integrar o cotidiano social, para, posteriormente, incidir na integração das diferentes linguagens constitutivas dos textos (multimodais e multissemióticos) que são socializados na contemporaneidade. Nessa dimensão, se no suporte impresso o processo de leitura já é considerado um fenômeno complexo, pois envolve sua capacidade simbólica e a interação com o outro pela mediação da palavra, essa complexidade se acentua no suporte digital, visto que inúmeras são as representaçôes simbólicas e ainda mais são diversificadas as interaçóes.

A formação de leitores na escola está, de forma dialética, ligada à formação de leitores para atuarem na sociedade, o que implica, necessariamente, a inserção de textos multimodais/multissemióticos no cotidiano escolar e, por extensão, uma reflexão acerca da concepção de letramento(s). Nesse viés, a participaçáo efetiva nas práticas sociais contemporâneas é marcada pela diversidade cultural, linguística e tecnológica, o que exige múltiplos conhecimentos, habilidades e procedimentos de natureza diversificada. Para que essa reconfiguração didáticopedagógica passe a integrar as práticas de ensino, é necessário compreender o que essa perspectiva demanda em termos socioculturais e, sobretudo, definir os aspectos que fundamentam a abordagem dos multiletramentos.

Para Rojo (2009), os letramentos abarcam vários tipos: múltiplos, multissemióticos e críticos. Para a autora, os letramentos múltiplos consideram os letramentos culturais, que buscam articular a dimensão local/regional com uma dimensão global/planetária, ou seja, significa deixar de "ignorar ou apagar os letramentos das culturas locais de seus agentes (professores, alunos, comunidade escolar) e colocando-os em contato com os letramentos valorizados, universais e institucionais" (p. 107). Os letramentos multissemióticos, por sua vez, são "exigidos pelos textos contemporâneos, ampliando a noção de letramentos para o campo da imagem, da música, das outras semioses que não somente a escrita" (p. 107). Os letramentos críticos são "requeridos para o trato ético dos discursos em uma sociedade saturada de textos e que não pode lidar com eles de maneira instantânea, amorfa e

5 Para Kress (2010), modo é uma forma socialmente e culturalmente determinada que oferece recursos para criar sentidos, como: a imagem, a escrita, a música, o gesto e a fala, etc. Cada modo possui seu conjunto de recursos semióticos, que van Leeuwen entende como [...] as açóes e os artefatos que usamos para nos comunicar, sejam eles produzidos fisiologicamente - com nosso aparelho vocal, com os músculos que usamos para criar expressóes faciais e gestos, etc. - ou por meio de tecnologias - com caneta, tinta e papel; com hardware e software de computador, com tecidos, tesouras e máquinas de costura, etc. (LEEUWEN, 2006, p. 3). 
alienada" (p. 108). Esses tipos de letramentos permitem articular a multissemiose/ multimodalidade das mídias digitais, as múltiplas práticas de letramentos sociais e a multiculturalidade advinda das diferentes culturas locais.

Complementando o exposto, Stokes (2002 apud SILVINO, 2012) faz referência ao letramento visual, que pode ser definido como a habilidade de ler, interpretar e entender a informação apresentada em imagens pictóricas ou gráficas e também de transformá-la em imagens, gráficos ou formas que ajudem no processo de construção dos sentidos. Esse tipo é contemplado por Rojo (2009), na tipologia de letramentos multissemióticos.

Xavier (2005) discorre sobre o letramento digital - que se refere às práticas sociais que exigem um adequado aproveitamento das vantagens e dos recursos que as tecnologias propiciam. $\mathrm{O}$ autor pontua que ser um sujeito letrado digitalmente pressupóe assumir mudanças nos modos de ler e de escrever os códigos e sinais verbais e não verbais, como imagens e desenhos, pois o suporte digital se diferencia dos demais suportes textuais. Esse tipo de letramento advém das condiçôes sociais, culturais e tecnológicas que evidenciam a necessidade da aquisição do letramento digital, o que parece estar contemplado pelos três tipos de letramentos expostos por Rojo (2009).

Desse modo, configura-se a existência paralela de vários tipos de letramentos, pois o letramento não é o mesmo em todos os contextos. Se existem diferentes tipos de letramentos, reitera-se que uma nova concepção de leitura se constitui, pois novas formas de se conceber a leitura e o ato de ler emergem a partir das discussóes acerca de sua prática em ambiente digital/virtual. Assim sendo, aprender e ensinar não se reduz a estratégias de aquisição e/ou transmissáo de conhecimento, mas a desconstrução e a reconstrução de identidades, culturas, comunidades e instituições (TAKAKI, 2012).

Nesse viés, para inserir-se socialmente, de modo efetivo, sob a ótica dos letramentos expostos, faz-se necessário saber ler e escrever numa perspectiva da interaçáo, ou seja, saber fazer uso da leitura e da escrita, levando em conta o contexto, a situação e a cultura de cada espaço social. Nesse percurso, o termo "multiletramentos" parece abarcar as diferentes categorias de letramentos indicadas pelos autores estudados, uma vez que contempla questóes de natureza diversa, tais como: linguístico-discursivas, culturais, ideológicas, tecnológicas, multissemióticas/ multimodais etc.).

Nessa direção, os processos de ensino e de aprendizagem da leitura devem compreender a multimodalidade, que se refere às mais distintas formas e modos de representação utilizados na construção linguística de uma dada mensagem, tais como: palavras, imagens, cores, formatos, marcas/traços tipográficos, disposição da grafia, gestos, padrôes de entonação, olhares etc., (DIONÍSIO, 2005). Abrange, portanto, a escrita, a fala e a imagem. O processo de leitura, assim dimensionado, contempla os diferentes modos de representação: imagens, música, gestos, sons, além dos elementos linguísticos nas análises dos textos. 
Segundo Gomes (2010, p. 96), essa tendência se revela em duas dimensões: “a) a descentralização da linguagem como favorecedora da construção do sentido; b) um novo olhar sobre os cada vez mais tênues limites entre os papéis da linguagem, da imagem, do suporte, do layout, do desenho do documento, etc.".

Ao se discutir a questão da descentralização da linguagem (do verbal para o multimodal) como promotora de sentido, reconhece-se que cada modalidade expressiva (texto verbal, som, imagem) integra um conjunto diferenciado de significados possíveis e esse "novo olhar" indicia que a combinação entre texto verbal e não verbal se torna uma ferramenta de mediação na constituição de identidades sociais e relaçóes entre elas. $\mathrm{O}$ entendimento sobre como os recursos da linguagem verbal, das imagens e da retórica digital podem ser empregados independente e interativamente para construir diferentes tipos de significado se constitui como uma habilidade leitora inerente aos pressupostos dos multiletramentos.

Nesse sentido, o texto não é construído linguisticamente apenas por meio da escrita, ao contrário, ele pode se materializar por meio da linguagem escrita, oral e/ou imagética, bem como da articulação/integração dessas modalidades. Para Dionísio (2005, p. 131), "na atualidade, uma pessoa letrada deve ser [...] capaz de atribuir sentidos a mensagens oriundas de múltiplas fontes de linguagem, bem como ser capaz de produzir mensagens incorporando múltiplas fontes de linguagem", ou seja, recursos visuais (ícones, imagens, cores, tipos de letras, combinação de letras, de palavras, de frases etc.) e recursos sonoros (sons, ruídos, gravação de falas, combinação de sons com textos falados etc.) são indiciadores de sentidos.

Os processos de ensino e de aprendizagem da leitura, dimensionados na perspectiva dos multiletramentos, favorecem uma ampliação da concepção de texto, pois rompem com a tradicional didática da escolarizaçáo do leitor que atribui primazia à linguagem verbal (escrita), focalizando, sobretudo, práticas que direcionam para uma perspectiva monomodal (FERRAZ, 2011). A proposta dos multiletramentos legitima o papel do letramento tradicional, mas enfatiza a complementaridade entre formas de letramentos, as quais envolvem leitura e escrita da linguagem verbal em interação com novas formas de negociação de significado, baseadas na manipulação de diferentes recursos semióticos, como imagens e sons, em uma perspectiva multimodal, que se refere à percepção de que os padrōes de significação são produtos de diferentes contextos e envolvem a manipulação de diferentes modos semióticos. Assim, analisar a inter-relação entre os diferentes recursos constitutivos dos diversos gêneros discursivos - concretizados em suas diferentes estruturas composicionais, em seus suportes, em suas funçôes comunicativas, com seus estilos de linguagem - é essencial para uma adequada percepção de como as combinaçóes dos modos semióticos criam significado a fim de alcançar os propósitos definidos em cada prática social.

Discorrendo sobre essa questáo, Kress e van Leeuwen (2006) apontam a necessidade de práticas pedagógicas que incitem ao aperfeiçoamento das habilidades de questionar, interpretar e criticar os recursos multissemióticos. Para os autores citados, a multimodalidade contempla um texto em seu todo significativo, ou seja, na 
inter-relaçáo entre seus diferentes elementos constituintes. Assim, o empoderamento semiótico depende da compreensão das diferentes semioses presentes em cada gênero e deve partir dos seguintes pressupostos: a) as imagens visuais podem ser lidas como um texto; b) a multiplicidade de significados dos textos multimodais deve estar pautada nos seus contextos sociais; c) as imagens visuais, como a linguagem e todos os modos semióticos, são socialmente construídas. Para Santos e Souza (2008, p. 4), "as imagens nunca devem ser encaradas de maneira inocente e devem ser sempre analisadas considerando-se sua dimensão sócio-ideológica”. Rojo (2012) assegura, ainda, que a sociedade da informação funciona a partir de uma diversidade de linguagens e de mídias e de uma diversidade de culturas e que essas questôes precisam ser tematizadas na escola. Nessa perspectiva, Unsworth (2001) considera que o aluno precisa entender que existem três linguagens: a verbal, a visual e a digital, e que elas sáo, ao mesmo tempo, independentes e interativas na criação de significados.

A despeito dessas consideraçóes, pode-se reiterar que os multiletramentos pressupóem a assunção de um ponto de vista conceitual em que a discussão sobre os modos de ler e escrever náo se restringe apenas à leitura e à escrita de textos verbais, mas se estende à leitura dos códigos e sinais verbais e não verbais, como imagens e desenhos, em seus diferentes suportes.

\section{Princípios basilares da gramática do design visual (GDV)}

Antes de caracterizar os princípios sob os quais se assenta a teoria da Gramática do Design Visual, é importante discorrer, ainda que brevemente, sobre a Semiótica Social da linguagem, campo em que se insere a GVD e que pode iluminar teoricamente a atividade docente.

As discussóes sobre os gêneros discursivos que circulam em ambientes digitais têm se ampliado substancialmente, entretanto, pela complexidade dos aspectos semiótico-discursivos que lhe são constitutivos, as análises linguísticas têm apresentado limitaçôes em funçấo da pluralidade de recursos que compóem os textos, tais como: linguagem verbal, segregaçôes, imagens, cores, divisões em páginas. Assim, todos são recursos possíveis e constitutivos da enunciação digital (cf. XAVIER, 2009). Além da pluralidade, há um entrelaçamento de modos semióticos (palavras, imagens, sons, cores, tipografias, movimentos, perspectivas, enquadramentos etc.) que é determinante para a produção dos sentidos, seja em percursos de leitura direcionados pelo autor do texto lido, seja em percursos construídos pelo próprio leitor (possibilidade de se conectar a outros textos por intermédio de links).

Nessa direção, Kress (1997 apud SANTOS, 2011) considera que esses textos (denominados de multimodais) são constituídos por modos semióticos que se compóem como formas sistemáticas e convencionais de comunicação própria da era da multimodalidade. Para o autor, a semiótica social constitui-se como um campo de investigaçóes que demanda estudos mais sistematizados. Essa ciência se ocupa da análise dos signos na sociedade, cuja função principal é o estudo da troca 
de mensagens veiculadas por signos verbais ou não verbais, ou seja, das interaçóes que se estabelecem nos diversos contextos sociais. Nessa teoria, as diversas formas de representação são denominadas modos semióticos.

A Semiótica Social fundamenta-se na Gramática Sistêmico-Funcional (GSF), de Halliday (2004). Para o pesquisador, a língua possui uma funçáo social, ou seja, é um sistema que influencia e é influenciada pelos usuários, em que o falante faz determinadas escolhas em detrimento de outras. Como contribuição, a GSF fornece um cabedal teórico importante para que se compreender o como e o porquê se fazem determinadas escolhas discursivas. Essa gramática estabelece três metafunções para fazer correlaçóes entre forma e significado no âmbito de um contexto global do discurso: ideacional, interpessoal e textual. $\mathrm{Na}$ metafunção ideacional, o usuário da língua constrói a realidade em torno de si, ou seja, organiza e incorpora na língua sua experiência dos fenômenos do mundo real. Na metafunçáo interpessoal, um usuário da língua interage com os outros usuários fazendo escolhas relativas à modalidade, à linguagem e a elementos constitutivos do evento da fala, expressando julgamentos e atitudes. Na metafunção textual, a relação explicita-se na organização do texto, na funçáo principal de organizar a linguagem como mensagem.

Halliday e Hasan (1989) sinalizam para a existência de uma relação sistemática entre a organização da língua e os elementos contextuais. Para os autores, a caracterização de um contexto de linguagem contempla três variáveis: a) o campo do discurso ou sobre o que a interaçáo trata; $b$ ) as relaçôes do discurso, ou os papéis desempenhados, e as relaçôes interpessoais presentes no discurso; c) o modo do discurso ou como a língua é organizada para atingir os objetivos aos quais se destina. Cada uma dessas variáveis contextuais se relaciona a uma das metafunçóes supracitadas: a) o campo do discurso é expresso pela metafunção ideacional; b) a relação entre os participantes é expressa pela metafunção interpessoal; c) o modo do discurso é expresso pela metafunção textual.

Considerando essas três metafunçōes, ou seja, a metafuncionalidade da linguagem, Kress e van Leeuwen (2006) propóem uma perspectiva de análise sistemática dos elementos visuais dos textos multimodais, denominada por Gramática do Design Visual, que descreve a forma pela qual indivíduos, coisas e lugares são combinados em uma totalidade constitutiva de sentido. Nessa concepção, as regras são socialmente produzidas e mutáveis por meio da interação social. Essa abordagem ajuda a desmistificar uma percepção generalizada de imagens e composiçóes visuais como meios de entretenimento desprovidos de significados ideológicos. Os modos semióticos, constituintes da linguagem não verbal, podem ser analisados em suas dimensôes sociais, políticas e comunicativas. Nessa direção, Kress e van Leeuwen (2006) criaram indicadores de análise, respectivamente, condizentes com as metafunçóes propostas por Halliday e Hasan (1989): a) ideacional => representacional; b) interpessoal $=>$ interativa e c) textual $=>$ composicional. Esses indicadores de análise atuam simultaneamente nos textos imagéticos, construindo padrões de experiência, interação social e posiçôes ideológicas a partir das escolhas relacionadas à realidade representada, à visáo de mundo apresentada, ao tipo de proximidade estabelecido entre os participantes da imagem e o leitor, às formas 
de construção dos participantes, às cores e texturas da imagem, aos gestos, às vestimentas, às expressóes faciais constituintes da organização da imagem etc.

Para Kress e van Leeuwen (2006), a metafunção representacional relaciona-se às potencialidades do sistema semiótico em representar objetos, ou participantes, e sua relaçáo com o mundo. Nessa direçáo, é possível reconhecer dois tipos de participantes envolvidos na composição semiótica: 1) participante interativo: pessoas reais - que produzem ou que consomem as mensagens -, 2) participantes representados: pessoas e objetos representados na imagem, que, por sua vez, podem se subdividir em: i) ator, quando partir deles partir o vetor e ii) meta, quando o vetor apontar para eles. Vetores equivalem-se linguisticamente aos "verbos". Nas imagens, os vetores sáo identificados a partir de linhas visíveis ou imaginárias formados pelos corpos, membros ou ferramentas em ação que indicam processos. Tais processos podem ser caracterizados por dois tipos: narrativos e conceituais. O tipo narrativo é percebido quando o participante está conectado por um vetor, ou seja, quando ele é representado como fazendo algo para alguém. Esse tipo pode se efetivar por meio de cinco processos:

a) processo de ação: quando os acontecimentos do mundo material são descritos ou apresentados, sendo que o participante é o ator, participante de quem o vetor parte, e o alvo, participante que é atingido pelo vetor. Esse tipo de estrutura corresponde aos processos materiais e comportamentais, no modo verbal, e dois tipos são diferenciados: (i) não transacional: a ação não é feita para alguém ou algo; corresponde ao verbo intransitivo (possui apenas um participante, o ator); (ii) transacional: a ação é feita para alguém ou algo; corresponde aos verbos transitivos. Tem-se pelo menos dois participantes, o ator e o alvo. A ação pode ser ainda bidirecional, no qual o participante é ator e alvo da ação.

b) processo de reação: quando o vetor é formado pela direção do olhar de um ou mais participantes representados. É chamado de reator aquele participante que olha, podendo ser um ser humano, animal, ou qualquer objeto, desde que tenha olhos e seja capaz de expressáo facial, e de fenômeno aquilo para que ou aquele para quem se está olhando, podendo ser transacional (o olhar do participante dirigese ao fenômeno que, por sinal, está na imagem) ou não transacional (o olhar é direcionado para algo fora da imagem). Como não há o fenômeno, temos que imaginar para quem o participante está olhando.

c) processo verbal e mental: muito comum nas histórias em quadrinhos. São dizeres representados por balóes, sendo que o participante é o dizente (do qual emana o baláo que indica a fala) e o enunciado é o conteúdo inserido no baláo. Se o processo for constituído por um balão indicativo de pensamento, os participantes são os experienciador, aquele de quem parte o baláo, e fenômeno, o que está inserido no baláo.

d) processo de conversão: envolve uma mudança de status do participante, o retransmissor, que é, simultaneamente, alvo de uma ação e ator de outra. Esse tipo de estrutura visual é comumente encontrado em diagramas que representam 
eventos naturais (ciclo da água, por exemplo), mas que também pode ser aplicado em (inter)açôes humanas.

e) processo de simbolismo geométrico: em que há somente o vetor, indicando direcionalidade por meio de um sinal de infinito, em vez de uma seta (PIMENTA; MAIA, 2014).

Além das questôes expostas, Kress e van Leeuwen (2006) admitem a existência de participantes secundários que se relacionam com os participantes principais, por meio de outras formas não vetorizadas, as quais são denominadas de circunstâncias: a) de lugar: que consiste no contraste entre primeiro e segundo plano; b) de meio: em que não há um vetor nítido entre a ferramenta e o seu usuário; c) de acompanhamento: em que participante está "com" o outro.

Já as imagens conceituais apresentam três tipos diferentes de processos:

a) classificacional: em que os participantes se relacionam, exercendo papéis diferenciados de subordinado e subordinante ou de participantes intermediários. Essas relaçóes podem ser: i) implícitas: em que os participantes subordinados são distribuídos simetricamente no espaço da imagem, em distância e tamanho iguais e orientados para os eixos vertical e/ou horizontal. O subordinante tem a possibilidade de ser inferido pela semelhança ou pelo motivo de estarem agrupados; ii) explícitas: em que um participante subordinante é ligado a dois ou mais participantes subordinados por meio de uma estrutura de árvore. O subordinante é colocado acima ou abaixo dos subordinados. Aqui, os participantes podem ser realizados verbalmente ou visualmente, ou em ambos, mas o processo é sempre visual.

b) Analítico: em que os participantes se relacionam em termos de uma estrutura de parte-todo, um deles o portador, o todo, e o outro o atributo, a parte. Podem aparecer setas, mas que não são vetores, elas apenas realizam uma identidade entre verbal e visual.

c) Simbólico: diz respeito ao que um participante significa ou é, podendo ser atributivo, quando a identidade de um participante (portador) é estabelecida na relação com outro participante (atributo), ou sugestivo, quando o participante representa a própria identidade (PIMENTA, MAIA, 2014).

A metafunção interacional (ou interpessoal) relaciona-se às interaçóes estabelecidas entre os participantes interativos (produtor da imagem e seu observador) e participantes representados. Segundo Kress e van Leeuwen (2006), essas representaçóes podem ser efetivadas por meio dos seguintes mecanismos:

a) olhar: que marca uma maior ou menor interação com o leitor, pode-se classificar como demanda - o PR olha diretamente paro leitor (PI) - e oferta - o PR olha para o leitor de maneira indireta;

b) enquadramento/distância entre os participantes interativos e os participantes representados: que pode representar uma relação imaginária de maior ou menor distância social, pode ser percebida a partir dos vários tipos de enquadramento: plano fechado (cabeça até ombros); plano médio (cintura para cima); plano aberto (todo o corpo do participante). Tais enquadramentos realizam um contínuo e, conforme 
a escolha mais próxima de um ou de outro, eles representam os participantes como mais íntimos de quem os observa ou como mais distantes ou estranhos;

c) perspectiva: evidenciada a partir da escolha do ângulo ou ponto de vista a partir do qual os participantes representados são retratados. Três são os ângulos que determinam a subjetividade da imagem em relação aos seus espectadores: i) ângulo frontal: apresenta a imagem no nível do olhar do PI; estabelece o envolvimento entre os participantes, na qual o primeiro é convidado a fazer parte do mundo retratado na imagem; ii) ângulo oblíquo: transmite um sentido de desconexão, apresentando o PR de perfil, revelando que aquilo que se observa náo pertence e nem pertence ao mundo do observador; iii) ângulo vertical: aponta para as diversas relaçóes de poder que são possíveis de acontecer na composição imagética entre os PR e os PI. Esse ângulo pode ser analisado em suas variaçôes. Assim, um ângulo frontal indica uma atitude notadamente subjetiva por parte do produtor da imagem. As imagens subjetivas sáo retratadas a partir de um ponto de vista escolhido pelo produtor e imposto tanto aos participantes representados quanto aos observadores, denotando envolvimento e relaciona-se à ação. Já o ângulo oblíquo/superior representa as imagens objetivas, que são produzidas para indicar imparcialidade e para expressar poder, relacionando-se ao conhecimento. "Tem-se, assim, que as imagens objetivas mostram o participante representado da forma como ele é, ao passo que as imagens subjetivas o mostram como ele é visto a partir de um determinado ponto de vista do produtor da imagem" (SANTOS, 2011, p. 7);

d) modalidade: que se refere à credibilidade das mensagens, ou seja, o conteúdo é verdadeiro, efetivo, real, ou é incoerente ou uma ficção. Para as autoras, "a modalidade determina a realidade dos PR na imagem por meio de recursos que podem torná-los reais ou irreais para os PI." (p. 13). A modalidade pode ser observada sob quatro dimensóes: a) naturalística: as cores representam o real, indiciando verdades. Já a ausência de cores (preto e branco) simboliza o irreal. Assim, quanto mais cor, mais real, quanto menos cor, menor é o grau de realidade; b) abstrata: a verdade visual é a verdade abstrata, expressa na imagem; se as cores apresentarem tonalidade maior ou menor que a realidade concreta, elas passam a expressar sentimentos e emoçóes; c) tecnológica: a verdade é baseada em uma utilidade prática da imagem), é comum em contextos científicos, informativos e apresenta apenas o que é essencial para a representação de uma imagem, como plantas e projetos arquitetônicos. Aqui, as cores e a iluminação são consideradas irrelevantes e; d) sensorial: a verdade visual tem por base a consequência de prazer ou desprazer criada pelo visual. Esse mecanismo é utilizado em contextos de assuntos prazerosos: fotografias de comida, anúncios de perfume etc. (cf. VAN LEEUWEN, 2006). Nessa direção, observa-se que a função discursiva das mensagens é mobilizada no processo de produção ou de leitura das composiçôes imagéticas.

A metafunção composicional, na teoria de Kress e van Leeuwen (2006), é constituída pela posiçáo dos elementos que compóem a imagem, a saber:

a) valor da informaçáo: diz respeito à posiçáo ocupada por cada elemento dentro da imagem. Cada posição possui um valor: se da esquerda para a direita 
(mais comum na sociedade ocidental), se na parte inferior ou superior, se centrado ou perto das margens. Assim, a noçáo de "dado" se refere aos elementos colocados à esquerda (informaçóes dadas, conhecidas pelo leitor) e de "novo" se refere aos elementos colocados à direita (informaçóes que o leitor necessita ser informado). De acordo com Pimenta e Maia (2014, p. 136), "informaçóes posicionadas à direita são tidas como o ponto de partida da mensagem, o senso comum, aquilo que é passivo, enquanto aquelas posicionadas à esquerda dizem respeito àquilo que se quer atenção especial, ao que é novo, ou problemático". Além disso, Kress e van Leeuwen (2006) exploram a noção de "ideal" que se refere aos elementos presentes na parte superior e que oferecem informaçóes mais idealizadas, como algo que possa despertar as emoçóes e/ou a imaginaçáo do leitor (promessa de algo ou produto, como em propagandas) e de "real" que se refere aos elementos presentes na parte inferior e que se refere à informação que tendem a ser mais práticas, objetivas, ligadas ao mundo real. Nesse quesito, os autores ainda exploram a noção de centro/ margem, pois as posiçóes centrais e marginais também são importantes para a análise de textos imagéticos. O elemento apresentado ao centro é o núcleo da informação, enquanto os que aparecem às margens relacionam-se à informação central;

b) saliência: está relacionada aos destaques e às acentuaçóes, como: efeitos de cores, tamanho e contrastes, localizaçáo no primeiro plano, moldura distintiva e profundidade de foco. Para Pimenta e Maia (2014, p. 137), esse mecanismo "é responsável por criar uma hierarquia de importância entre os elementos, selecionando alguns como os mais importantes e mais dignos de atenção que outros. Isso ocorre através do contraste de tamanho entre os participantes representados, e também se eles estão em primeiro ou segundo plano";

c) enquadramento: conecta ou desconecta os elementos de uma imagem, indicando se pertencem ou não à informação central. São realizadas por linhas divisórias e espaços coloridos ou não, dentro ou nas margens da imagem.

Os mecanismos representacionais, interativos e composicionais apresentados sáo constitutivos das composiçóes visuais e oferecem possibilidades para o encaminhamento do processo de leitura e, consequentemente, para o aperfeiçoamento das habilidades de leituras das imagens que constituem os diversos gêneros que circulam na sociedade de informação, em que as interaçóes realizadas em ambientes digitais têm se ampliado de forma exponencial.

Nessa direção, considera-se que, a partir dos mecanismos apresentados nesta seção, é possível propiciar ao professor fundamentos teóricos e metodológicos que permitam a "compreensão de texto não verbal, com vistas à produção de sentido na atividade de leitura pautada em critérios sistematizados, de modo a evitar leituras intuitivas" (DUARTE et al., 2016, p. 6). Assim, a GDV pode se constituir como um marco orientador para a análise da articulação entre os modos e os recursos semióticos para a compreensão do projeto de sentido proposto pelos produtores que realizam uma ação enunciativo-discursiva nas intersecçôes estéticas e técnicas da composição imagética. 
Nessa perspectiva, conforme Ferreira (2019, p. 42-43), a GDV apresenta subsídios teóricos e metodológicos capazes de

fundamentar o trabalho do professor, de modo que o estudo dos modos de organização dos textos esteja pautado em pressupostos teóricos que concebam as produçóes imagéticas como constructos culturais e que carregam valores, crenças e ideologias. Nesse sentido, os diferentes recursos semióticos integram os textos, indiciam sentidos, desvelam tradiçóes, orientam interpretaçóes, evidenciam um querer dizer e modos de conceber o mundo. Além disso, uma prática pedagógica teoricamente orientada pode contribuir para a formaçáo de cidadãos capazes de analisar criticamente os textos que circulam na sociedade da informaçáo e comunicação. Nesse sentido, a GDV constitui-se como um consolidado das tendências da cultura ocidental, que apresenta um arcabouço teórico que toma as produçóes imagéticas em três formas: modos de representação, modos de interação, modos de composição dos textos. Essas formas são analisadas sob a perspectiva não apenas de sua organização estrutural, mas também discursiva, uma vez que contemplam diferentes instâncias do processo de comunicação/interação.

Ao abarcar as três metafunçôes, a GDV sinaliza para uma abordagem mais ampliada do processo de leitura dos textos multissemióticos. Na metafunção representacional, há a possibilidade de consideraçáo de um olhar atento para as escolhas relacionadas à construção dos personagens constitutivos das cenas imagéticas, que compreendem não somente pessoas, mas também objetos, cenários etc. Desse modo, uma proposta de leitura, nessa ótica, proporciona uma abordagem que possibilita não somente analisar como os participantes interativos (PI) e participantes representados (PR) são construídos, mas, também, como essas escolhas orientam a interpretação. $\mathrm{Na}$ metafunção interativa, há uma sinalização para os processos de interaçáo entre os sujeitos - produtores e interlocutores, uma vez que são contemplados os mecanismos relacionados à relevância de determinados aspectos em detrimento de outros. Na metafunção composicional, há a consideração dos recursos que compóem a cena enunciativa e os modos como esses recursos estão organizados como eles se articulam para a produção de sentidos.

Diante do exposto, Ferreira (2019) complementa que a GDV "implica o sujeito-produtor do texto, o sujeito-leitor, as representaçóes dos personagens, as escolhas semióticas, a materialidade linguístico-semiótica e seus modos de organização" (p. 42). Essa abordagem ampliada dos processos de organização e de funcionamento dos textos multissemióticos pode auxiliar o professor a compreender a complexidade das produçóes que congregam diferentes linguagens.

\section{Procedimentos metodológicos}

O presente trabalho se caracteriza como um tipo de pesquisa teórica em que se buscou compilar pesquisas sobre a concepção de multiletramentos e dos pressupostos basilares da teoria da Gramática do Design Visual. Para ilustrá-lo, foi construída uma proposta de exploração de uma campanha educativa, utilizando como arcabouço teórico-metodológico a Gramática do Design Visual, tal como concebida por Kress e van Leeuwen (2006). A proposta se insere no campo da Linguística Aplicada, que 
concebe como uma pesquisa crítica aquela que estabelece uma relaçáo entre teoria e prática e que aponta para as açóes humanas - aqui dimensionada nos processos de ensino e de aprendizagem de leitura de textos imagéticos. Segundo Celani (2005), no âmbito da Linguística Aplicada, a pesquisa crítica é entendida como um tipo de empoderamento sobre alguma coisa, para algum fim ou para alguém, assim, a análise foi realizada levando-se em conta as metafunçóes constitutivas dos textos não verbais. Como categorias de análise foram eleitos apenas os elementos presentes na campanha analisada, segundo os significados: representacionais, interacionais e composicionais, em suas subdivisóes.

A campanha analisada foi publicada no site http://www.gritodascinco.com. br/blog/wp-content/uploads/2012/04/limpeza_praia4.jpg. A foto é acompanhada de um texto que indica que as fotos de pescadores com seus pescados tornaram se clichês para indicar histórias sem provas contadas por diversos pescadores ao redor do mundo. Aproveitando isso, a sede francesa da Surfrider - ONG sem fins lucrativos, dedicada à proteçáo e ao cuidado dos oceanos, das ondas e das praias do mundo - resolveu divulgar os dias de limpeza das praias de uma maneira criativa e eficaz. A ONG divulga sua campanha utilizando uma foto de pessoas comuns segurando sujeiras retiradas do mar, como se fossem peixes gigantes. Suas expressóes retratam total orgulho na pesca realizada e os lixos apresentados variam desde botas e sandálias velhas a sofás. Todos os anúncios estão acompanhados do texto: "Sintase orgulhoso. Limpeza das praias entre os dias 22 e 25 de março".

Figura 1: Campanha educativa

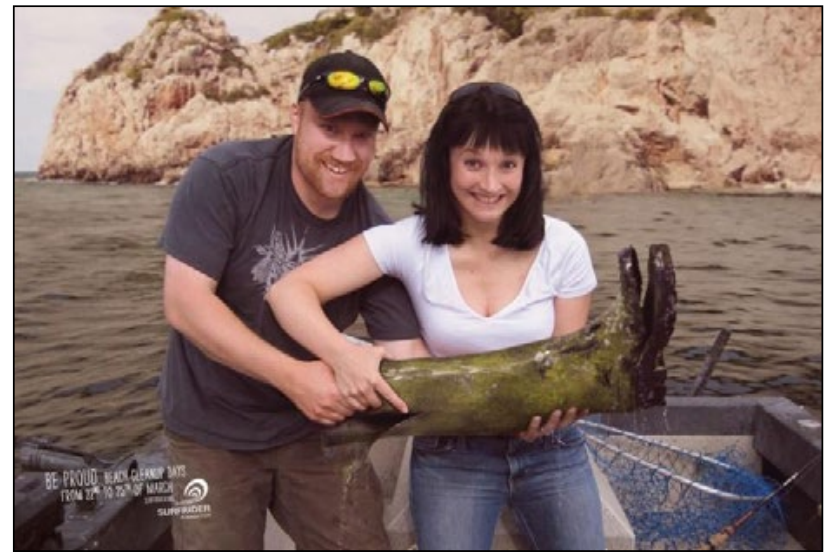

Fonte: https://adsoftheworld.com/media/print/surfrider_foundation_boot

O gênero em pauta se insere no domínio do texto publicitário e se intitula como campanha educativa. Uma campanha, tomada numa dimensão ampla, tem como objetivo mostrar para as pessoas as consequências de um comportamento inadequado. Assim, a campanha tem que ser propositiva, ou seja, deve apresentar ou oferecer condições para a viabilização de um instrumento de solução, apontar caminhos alternativos práticos que sejam factíveis para as pessoas mobilizadas 
agirem, estimulando a problematização e gerando a resolução do problema. A campanha educativa, como um gênero que possibilita condicionamento do homem a um determinado fazer, apresenta características recorrentes, colocando sujeitos participantes (produtor/ONG e receptor/leitor) em interação, organiza seus textos por meio de imagens, sons e de elementos linguísticos, entre os quais circulam sentidos determinados.

Assim, pode-se dizer que o texto publicitário é formulado a partir de textos verbais (escritos ou falados) e não verbais (imagens, sons, cheiros, texturas), e tal característica permite que seja considerado como um texto multimodal (KRESS; VAN LEEUWEN, 2006), que combina diferentes códigos semióticos. Uma campanha educativa é constituída por estratégias de persuasão utilizadas pelo produtor-anunciante, buscando seduzir o leitor-receptor; tais estratégias se constituem na inter-relação entre a linguagem verbal e a linguagem náo verbal. A imagem é constituída por uma cena única, estática, em que duas pessoas (supostamente marido e esposa) se apresentam como "pescadores", segurando um objeto (no lugar de um peixe) que rompe com o padrão tradicional de uma foto de pescaria. Há um pequeno texto em inglês com a inscrição: "Be proud. Beach cleanup days from 22nd to 25th of March".

Considerando a metafunçáo representacional, a análise ora empreendida parte dos conceitos de participantes interativos (PI) e participantes representados (PR). Os PI são aqueles que produzem e consomem a mensagem, no caso específico da campanha, o produtor (ou a ONG que o divulga) e o receptor (público em geral - pessoas que frequentam praias). São os que entram em uma relação de comunicaçáo por meio do texto e apresentam diferentes graus de envolvimento. A interaçáo entre os PI acontece por meio dos PR, ou seja, aqueles que podem ser chamados de personagens ou sujeitos: são as pessoas, lugares e coisas dos quais se fala. Assim, a interação aqui estabelecida se efetiva por meio dos consumidores (leitores), da instituição ONG, dos personagens (casal representando um ideal de família) e da bota velha (representando o lixo descartado de forma errada). Em situaçôes como essa, ocorre uma fusão entre participantes interativos (pessoas reais produtor/representante da ONG e leitores) e participantes representados (homem, mulher e objetos). Nesse caso, Kress e van Leeuwen (1996, p. 46) consideram que as categorias se obscurecem, tornando a relação ainda mais complexa. A escolha das imagens não é aleatória.

Os participantes representados indiciam a posição de "ator", tomada aqui acepção de Kress e van Leeuwen (2006), pois as linhas características do movimento de "segurar algo" estáo nitidamente delineadas, ou seja, há indicação de açáo. Esse processo pode ser considerado como narrativo, uma vez que os participantes estáo conectados por um vetor, ou seja, eles são representados "como fazendo algo para alguém" (KRESS; VAN LEEUWEN, 2006). Se se tomarem como referência os tipos de processos narrativos propostos pelos autores, pode-se considerar que se trata de um processo de ação, dimensionado numa perspectiva transacional. Já no que diz respeito ao processo de reaçáo, o vetor é formado pela direçáo do olhar de um ou mais participantes representados. Nesse caso, a abordagem é de natureza náo 
transacional (o olhar é direcionado para algo fora da imagem), uma vez que o olhar se direciona para o PI, evocando a interação.

No que diz respeito à metafunçáo interacional (ou interpessoal), o olhar dos PR se direciona para o PI, conforme já pontuado, que sinaliza para o tipo "demanda". Uma imagem de demanda é aquela em que o participante representado olha diretamente para o leitor. Segundo Brito e Pimenta (2009, p. 96), esse procedimento visa criar um vínculo direto com o leitor, como se estivesse dizendo um "você" visualmente. Assim, o participante representado quer algum tipo de relação imaginária com o leitor (afinidade, seduçáo, dominaçáo) demandando algo: uma aproximaçáo, no caso aqui trabalhado. Em relaçáo ao enquadramento, o plano pode ser considerado médio/aberto, pois é utilizado o close up para demonstrar maior intimidade com o participante interativo, possibilitando o compartilhamento de sensaçóes e sentimentos. Nesse caso, a posição dos braços e das mãos segurando um objeto (ressaltadas pela imagem) transmite sensaçáo de orgulho. Assim sendo, é possível inferir que é uma imagem metafórica que representa o orgulho pela ação de limpeza comunitária das praias. A perspectiva, representada por meio do ângulo frontal, apresenta a imagem no nível do olhar do PI, o que busca estabelecer um clima de envolvimento entre os participantes e igualdade de poder. Por fim, no que tange à modalidade, observa-se que há intençáo de imprimir credibilidade à mensagem por parte do produtor, uma vez que as cores são naturalísticas; há apelo sensorial, pois se busca por meio da verdade visual a provocação sentimental, ou seja, um apelo emocional.

Ao direcionar para a metafunção composicional, a análise proposta neste artigo, pautada em Kress e van Leeuwen (2006), descreve a imagem, considerando os seguintes aspectos: a) valor da informação: a imagem se circunscreve no critério de centro/margem, pois as posiçôes centrais e marginais são evidenciadas na constituição da campanha. O elemento apresentado ao centro é o núcleo da informaçáo - é o casal com a bota (lixo) nas mãos - enquanto os que aparecem às margens apresentam informaçóes complementares. A relação dado/novo incide sobre a importância dos elementos: do lado esquerdo, não há nenhum elemento em destaque; do lado direito, encontra-se uma rede, elemento indispensável para a pesca, e, consequentemente, para a coleta do lixo na água. No que diz respeito à noçáo de ideal/real, um destaque é a presença da bota e da rede, que aparecem na parte inferior, o que indicia uma informação mais concreta, objetiva, ligada ao mundo real. Já a saliência, a hierarquização dos elementos são evidenciadas por meio da projeção em primeiro plano da imagem dos personagens, que carrega o sentido global da campanha. $\mathrm{O}$ enquadramento explicita a conexão entre elementos da imagem, indicando uma associação semântica entre as partes (mar, praia, rede, barco, molinete, vestuário casual, óculos de sol, boné, rochedo etc.) que constituem a composição visual. Não há divisão por cores ou por forma, esses aspectos são integrantes dos recursos utilizados. Do mesmo modo, não há linhas divisórias que demarcam alguma desconexáo. Os elementos sáo dispostos na composição imagética de modo colaborativo para a constituição dos sentidos. 
Resta mencionar a articulação entre texto verbal e imagem, uma vez que a construção linguística "Sinta-se orgulhoso. Limpeza das praias entre os dias 22 e 25 de março" coaduna com a expressão corporal (manifestação de contentamento, posição dos braços típica de fotos de pescadores) presente na imagem. Além disso, cumpre com a função comunicativa de promover uma mobilização comunitária, conforme convite para a limpeza das praias, na data especificada.

Diante do exposto, é possível considerar que, por um lado, a leitura com os textos multissemióticos, desenvolvida em uma perspectiva teoricamente orientada, tal como os pressupostos da GDV aqui apresentados, pode qualificar os processos de produçáo de sentidos, uma vez que os diferentes recursos semióticos constituem escolhas por parte do(s) produtor(es) para a construçáo do projeto de dizer. Por outro lado, de modo articulado, esses recursos semióticos estão sujeitos às interpretaçóes por parte dos leitores, que mobilizam seus conhecimentos prévios para o reconhecimento das combinaçóes e para a (re)construçáo dos sentidos, uma vez que, segundo Joly (1996), a imagem passa por alguém que a produz ou a reconhece.

\section{Consideraçóes finais}

Esse artigo teve o objetivo de apresentar uma reflexão sobre o fenômeno da multissemiose constitutiva dos textos imagéticos, com vistas a vislumbrar possibilidades para o encaminhamento metodológico para o trabalho com a leitura em sala de aula. A partir de uma compilação teórica de autores que versam sobre os multiletramentos, foi possível reiterar a importância de se trabalhar com gêneros discursivos para a formação de um leitor proficiente, capaz de se adequar às demandas da sociedade da informação. Constatou-se a existência de vários tipos de letramentos, que podem ser agrupados sob a denominação de multiletramentos, já que as habilidades de usos sociais da leitura e da escrita se mesclam em função da diversidade de textos que circulam nos meios impressos e digitais.

Buscou-se, ainda, apresentar os princípios basilares da teoria proposta por Kress e van Leeuwen, intitulada de Gramática do Design Visual, que incorpora a discussão sobre o fenômeno da multimodalidade e sobre os processos de organização da sintaxe visual das produçóes imagéticas que circulam na sociedade ocidental.

Por fim, por meio da análise da campanha educativa, constituída predominantemente por uma imagem visual, em que se buscou explorar os elementos constitutivos, seus posicionamentos e suas funçóes para o processo de produção dos sentidos, foi possível constatar que uma proposta de leitura em sala de aula poderá contemplar aspectos presentes nas metafunções expostas, observandose os conhecimentos prévios dos alunos e as suas capacidades de aprendizagem. Notou-se que a leitura de composiçóes imagéticas é uma demanda escolar e social, pois os textos que circulam na contemporaneidade apresentam nova configuração de linguagens ao conjugar recursos multimidiáticos (fotos, vídeos, músicas, etc.). 
Nessa perspectiva, surge a necessidade de novas incursóes sobre as imagens estáticas ou em movimento, para um dimensionamento das questóes culturais, estéticas, científicos, técnicas, artísticas integrantes dos textos multissemióticos, de modo a minimizar leituras realizadas intuitiva ou ingenuamente. A consideração das relaçóes estabelecidas entre os elementos constitutivos e das referencialidades dos sentidos permite uma formação teórica e metodológica de professores para um enfrentamento da complexidade inerente ao processo de leitura de imagens, viabilizando o encaminhamento de práticas de ensino mais sistematizadas e teoricamente iluminadas.

\section{Referências}

BRASIL. Secretaria de Educação Fundamental. Parâmetros Curriculares Nacionais: língua portuguesa. Brasília: Secretaria de Educação Fundamental, 1998.

CELANI, M. A. A. Questôes de ética na pesquisa em linguística aplicada. Linguagem \& ensino. Pelotas: UCPEL, v. 8, n. 1, p. 101-122, 2005.

COSCARELLI, C. V.. Leitura numa sociedade informatizada. In: MENDES, E., et al. Revisitaçóes. Belo Horizonte: UFMG, 1999. p. 83-92.

DUARTE, Matheus Henrique; DIAS, Francieli Aparecida; FERREIRA, Helena Maria. Multimodalidade e multissemiose no processo de produção de sentido: uma análise da GDV. Anais do SIED: EnPED-Simpósio Internacional de Educação a Distância e Encontro de Pesquisadores em Educação a Distância, 2016.

FERRAZ, J. A. A Multimodalidade no Ensino de Português como Segunda Língua: novas perspectivas discursivas críticas. Tese de Doutorado, Programa de Pós-graduação em Linguística, Universidade de Brasília - UNB, 2011.

GOMES, L. F. Hipertextos multimodais: leitura e escrita na era digital. Jundiaí: Paco Editorial, 2010.

HALLIDAY, M. A. K. An introduction to functional grammar. 3a ed. rev. por C. M. I. M. Matthiessen. London: Edward Arnold, 2004.

HALLIDAY M. A K.; HASAN, R. Language, context and text: aspects of language in a social-semiotic perspective. Oxford: Oxford University Press, 1989.

FERREIRA, Isabella Bacha. Textos multissemióticos e novas habilidades de leitura: contribuiçōes para a formação docente. 2019. 92 f. Dissertação (Mestrado) - Curso de Pós Graduação em Educação, Universidade Federal de Lavras, Lavras, 2019. Disponível em: http://repositorio.ufla.br/bitstream/1/34353/3/DISSERTA\%C3\%87\%C3\%83O_ Textos $\% 20$ multissemi\%C3\%B3ticos $\% 20 \mathrm{e} \% 20$ novas $\% 20$ habilidades $\% 20$ de\%20leitura\%3A\%20contribui\%C3\%A7\%C3\%B $\%$ es\%20para\%20a\%20 forma\%C3\%A7\%C3\%A3o\%20docente.pdf. Acesso em: 23 nov. 2020.

JOLY, Martine. Introdução à análise da imagem. 4. ed. Campinas: Papirus, 1996. 
KRESS, G. Multimodality: a social semiotic approach to communication. London \& New York: Routledge, 2010.

KRESS, G.; VAN LEEUWEN, T. Reading images: the grammar of visual design. $5^{\text {th }}$. London and New York: Routledge, 2006.

PIMENTA, S. M. de O.; MAIA, D. G. Multimodalidade e letramento: análise da propaganda Carrossel. Desenredo, v. 10, p. 12-20, 2014.

ROJO, R.. O letramento escolar e os textos da divulgação científica - a apropriação dos gêneros de discurso na escola. Linguagem em (Dis)curso, v. 8, n. 3, p. 581-612, 2008.

2009.

. Letramentos múltiplos, escola e inclusão social. São Paulo: Parábola Editorial,

ROJO, R; MOURA, E. Multiletramentos na escola. São Paulo: Parábola, 2012.

SANTOS, F. R. da S.; SOUZA, M. Aspectos multimodais em editoriais da Veja. In:

Simpósio Hipertexto e Tecnologias na Educação, II, set. 2008, Recife. Anais. Recife:

NEHTE-UFPE, 2008, p. 1-16.

SANTOS, Z. B. dos. A concepção de texto e discurso para semiótica social e o

desdobramento de uma leitura multimodal, Revista Gatilho, UFJF: p.1-14, 2011.

SILVINO, F. F.. Letramento Visual. In: Anais dos Seminários Teóricos Interdisciplinares do SEMIOTEC - I STIS, 2012. Disponível em: http://www.periodicos.letras.ufmg.br/ index.php/stis. Acesso em 20 ago. 2015.

TAKAKI, N. H.. Letramentos na Sociedade Digital: navegar é e não é preciso. São Paulo: Paco Editorial, 2012.

UNSWORTH, L. Teaching multiliteracies across the curriculum. Maidenhead, UK:

Open University Press. 2001.

VAN LEEUWEN, T. Introducing Social Semiotics. New York: Routledge, 2006.

XAVIER, A. C. Letramento digital e ensino. In: FERRAZ, C; MENDONÇA, M.

Alfabetizaçáo e letramento: conceitos e relaçóes. Belo Horizonte: Autêntica, 2005.

XAVIER, A. C. A era do hipertexto: linguagem e tecnologia. Recife: Editora

Universitária/ UFPE, 2009. 